Article

\title{
Groundwater as a Source of Drinking Water in Southeast Asia and the Pacific: A Multi-Country Review of Current Reliance and Resource Concerns
}

\author{
Naomi Carrard $*$, , Tim Foster ${ }^{\circledR}$ and Juliet Willetts \\ Institute for Sustainable Futures, University of Technology Sydney, Sydney 2007, Australia \\ * Correspondence: Naomi.Carrard@uts.edu.au; Tel.: +61-9514-4950
}

Received: 24 May 2019; Accepted: 31 July 2019; Published: 2 August 2019

check for updates

\begin{abstract}
Groundwater is widely acknowledged to be an important source of drinking water in low-income regions, and it, therefore, plays a critical role in the realization of the human right to water. However, the proportion of households using groundwater compared with other sources is rarely quantified, with national and global datasets more focused on facilities-rather than resources—used. This is a significant gap in knowledge, particularly in light of efforts to expand water services in line with the inclusive and integrated agenda of the Sustainable Development Goals. Understanding the prevalence of groundwater reliance for drinking is critical for those involved in water services planning and management, so they can better monitor and advocate for management of water resources that supports sustainable services for households. This paper contributes data that can be used to strengthen the integration of resource considerations within water service delivery and inform the work of development partners supporting this area. We approach this issue from two perspectives. Firstly, we collate data on the proportion of households using groundwater as their primary drinking water source for 10 Southeast Asian and Pacific nations, finding an average of $66 \%$ (range of $17-93 \%$ for individual countries) of households in urban areas and $60 \%$ (range of $22-95 \%$ ) of households in rural areas rely on groundwater for drinking. Together, these constitute $79 \%$ of the total population across the case study countries. Secondly, we review current and emerging groundwater resource concerns within each country, using a systems thinking approach to assess how groundwater resource issues influence household water services. Findings support the case for governments and development agencies to strengthen engagement with groundwater resource management as foundational for achieving sustainable water services for all.
\end{abstract}

Keywords: groundwater; Southeast Asia; Pacific Island Countries; water services; human right to water; water resources; sustainability; Sustainable Development Goals

\section{Introduction}

Around the world, groundwater makes a critical contribution to progressive realization of the human right to water. In developing country contexts-where 2.1 billion people still lack access to safely managed water and 844 million lack even basic water [1]—development of groundwater is considered a key strategy for addressing gaps in service delivery [2] and for building resilience to the impacts of climate change [2,3]. Groundwater is already the preferred source of drinking water globally [4], often considered more reliable than surface water and more accessible, given it can be directly exploited by users [5]. However, data on actual use is lacking, with knowledge gaps evident across local, regional and global scales [6].

Meanwhile, there is recognition by hydrogeology scholars that groundwater resources are under threat from overexploitation and pollution. Overexploitation is occurring in a context where 
groundwater has shifted in status from "a reserve resource" used in periods of scarcity to "one that is now systematically abstracted in an uncontrolled or unregulated manner" [7]. With management and regulation yet to adequately respond in many contexts, groundwater remains poorly understood and inadequately protected [8]. The result is widespread stress on groundwater resources, with an estimated 1.7 billion people living in areas affected by overexploitation [9]. At the same time, groundwater quality is under threat from an ever-increasing list of anthropogenic pollutants [5]. With groundwater constituting $98 \%$ of the world's freshwater reserves [2], a focus on the governance of groundwater resources is essential to ensure we remain within the safe threshold of the freshwater use planetary boundary $[10,11]$.

In this context, efforts to ensure sustainable, safe drinking water supplies must consider the relevant water resource and its management. For the global water, sanitation and hygiene (WASH) sector-comprising development organizations, researchers and government agencies responsible for service delivery-this requires a greater focus on the resources underpinning water supplies. As argued by Bradley and Bartram [12], WASH professionals need to give higher priority to water resources management, especially to groundwater management, and to consider water services and water resources management together in spite of their typical institutional separation. Recently, efforts have been made at the global level to better situate WASH services within broader water resource management (WRM), evidenced by the integration of WASH and WRM within a single Sustainable Development Goal (SDG). Guided by the SDG framework, those working on water service delivery are prompted to think about domestic water supply (target 6.1) in tandem with the quality of water resources (target 6.3), water-use efficiency (target 6.4) and water resource management (target 6.4). This promotes a broadening in WASH discourse, which has focused on the health, social and economic aspects of water services, and has placed less emphasis on their underpinning resources [13].

The neglect of resource considerations in WASH discourse reflects the fact that domestic use of groundwater is not typically considered a threat to groundwater resources, with agriculture dwarfing the domestic sector in terms of volumes extracted. Agriculture accounts for an estimated $70 \%$ of groundwater withdrawals worldwide, with the domestic sector responsible for just over $20 \%$ and industry just under 10\% (based on 2010 data) [5]. However, a focus on total extractions obscures the critical link between resource management and households' access to water. Although household water use alone might not lead to overexploitation of groundwater resources, households reliant on groundwater have a central interest in its management and sustainability. Further, a global perspective on the contribution of domestic demand to total water extraction conceals local variations which can be important. For example, growing urban centers can have substantial water demand [14] and may be sites of localized groundwater stress. It is important to maintain the quality of raw water used for domestic purposes in order to protect human health and avoid expensive water treatment. Groundwater quality has a major bearing on the cost of using it for different purposes [15].

In recent years, integration of water resource considerations into WASH sector thinking is emerging in a number of evolving frameworks guiding service planning, delivery and oversight $[12,16,17]$. In the rural water sector, recent evolutions of the service delivery approach, which offers a widely used guiding frame for sector analysis and strengthening, include 'water resources management and security' as one of five building blocks for sustainable service delivery [18]. The inclusion of water resources within the service delivery approach framework acknowledges the growing recognition by governments of the challenges of both physical and economic water scarcity [18], and represents a notable shift compared with earlier iterations, which emphasised institutional, financial, asset management and monitoring considerations [19] but did not include resources. The service delivery approach articulates three institutional levels comprising national agencies, service authorities and service providers. Within this framing, the scope of focus on water resources considers both water availability and quality as well as institutional links between water resource managers and the service authorities and providers responsible for drinking water [18]. 
In metropolitan areas, there is a longer history of integrating resource considerations into the way water services are conceived and planned. Frameworks that have been applied to developing cities include Integrated Urban Water Management (IUWM) [20], sustainable urban water management (SUWM) [21], Water Sensitive Cities [22] and Nature Based Solutions [23]. Resource conservation and protection feature across 17 principles for water-wise cities developed by the International Water Association to support sustainable urban water management that links services with basins [24]. However, the extent to which these frameworks have put into practice has been variable [20,22], with particular challenges applying them in developing cities [22]. Further, Howard [25] argues that models for holistic urban water management have not adequately addressed the particularities of groundwater resource systems, despite advances in urban groundwater science, and identifies a need for involvement of all stakeholders in decision-making processes that inform groundwater governance. This includes a more proactive role for water utilities in groundwater resource management, mobilizing their technical expertise, as argued by Foster and Sage [26].

If the WASH sector is to adequately integrate resource considerations within service delivery approaches and progressive realization of the human right to water, it is essential to acquire a better understanding of which resources are used. In tracking progress towards SDG 6.1, the WHO/UNICEF Joint Monitoring Program (JMP) collates comprehensive data on facilities used by households for drinking water, including the type of resources used for water points, such as wells, springs or rainwater tanks. However, for those using piped or packaged water, the resource supplying these systems is not consistently identified in any standardized monitoring. With the increasing use of piped and packaged water [1,27], there is a growing knowledge gap about the extent to which households rely on groundwater. This is evidence of the "paucity of well-structured, globally useful, up-to-date and SDG-relevant groundwater data available", as found by Guppy et al. [4] in their analysis of the interlinkages between groundwater and the SDGs.

Addressing this gap, this paper offers an analysis of the role of groundwater in supplying drinking water services across ten Southeast Asian and Pacific Island countries. We approach the issue from two perspectives: (i) Integrating available data to calculate the proportions of households using groundwater as their primary source of drinking water, which we define as 'groundwater reliance' given the critical role of drinking water in supporting human health, and (ii) synthesising literature on the status of groundwater resources and emerging pressures, and undertaking a systems analysis of the links between resource issues and water service delivery. The intention is to contribute to WASH sector discourse and direction-setting by establishing a baseline of proportions of households using groundwater for drinking in each country, and identify the breadth of resource issues that must be considered, analyzed and planned for as part of efforts to expand, and sustain, services. In taking a multi-country approach, we sought to uncover the breadth and diversity of experiences, which can guide the scope and focus of much-needed future sub-national and local analyses.

\section{Materials and Methods}

This study involved the review and synthesis of secondary sources, with the investigation framed by two research questions:

(i) To what extent are households in Southeast Asian and Pacific case study countries reliant on groundwater for their primary source of drinking water?

(ii) In case study countries, how do groundwater resource issues currently influence water services for groundwater-reliant households, and how are they likely to do so in future?

Case study countries were selected to represent the diversity of countries across Southeast Asia and the Pacific, based on criteria including region (six from Southeast Asia and four from the Pacific), geography (island, coastal and land-locked nations), level of development and extent of urbanization. In selecting a diverse set of countries, the intention was to achieve breadth in the analysis of groundwater use and resource issues evident across the region, which can inform deeper contextual analyses at 
national and sub-national scales in future. The countries chosen from Southeast Asia are: Cambodia, Indonesia, Lao People's Democratic Republic (PDR), Myanmar, Timor Leste and Vietnam. Those from the Pacific are: Kiribati, Papua New Guinea (PNG), Solomon Islands, Vanuatu.

\subsection{Calculating Household Groundwater Reliance}

To answer the first research question, data were collated from the WHO/UNICEF JMP and country sources, including utility information and sector reports. Information was sought separately for urban and rural areas because differences in their typical water supply profiles would be obscured in aggregated national datasets. The most recent complete dataset from each of the JMP country files was used to identify proportions of households using point-source groundwater, tap water or packaged water as their primary drinking water service. The study sought to identify the overall quantum of groundwater reliance, so it was concerned with identifying water source rather than whether the facilities were defined as safely managed, basic, limited or unimproved according to JMP definitions. Further, we acknowledge that a focus on primary drinking water services obscures the reality that many households use more than one water source across seasons and for different purposes [28]. However, given multiple water source use (MWSU) is an emerging area of research with limited consistent data available to date [28], our approach was to focus on the primary source of drinking water in line with the methodology used to track SDG target 6.1.

Country-specific data were used to assess the proportion of tap water and packaged water sourced from groundwater. In this analysis, both aquifer and spring sources were defined as groundwater given they are both subject to aquifer resource issues. Targeted internet searches were used to identify data on sources used for piped and packaged water. For our calculations data from online databases (e.g., utility benchmarking), peer-reviewed literature and sector reports were preferred. However, company websites and media reports were used when they were the only available sources, which was typically the case for water sources used for packaged water.

Collated data provided the basis for calculating the proportion of households using groundwater in each country. Where there was uncertainty, conservative choices were made to avoid overstating the extent of reliance. Additionally, when there was any doubt about the inclusion or exclusion of particular figures for a given country, a minimum or maximum estimate was calculated to show the range of uncertainty (these figures are shown in Supplementary Materials). Finally, initial calculations were shared with sector experts in case study countries to sense check the assumptions and logic used. The data sources and assumptions underlying the calculations for each case study country are described in full in Supplementary Materials.

In analyzing data from diverse sources, it was necessary to reconcile a mismatch in unit of analysis between drinking water and domestic water more broadly. JMP datasets focus on drinking water only (taking a user perspective), while country-specific information is typically more supplier-oriented, describing either sources of water for domestic supply generally (for both consumptive and non-consumptive purposes) or sources for supplying all users across domestic, industrial and commercial sectors. To address the potential for this mismatch to affect estimates of household groundwater reliance, we compared data on facilities used for drinking and non-drinking purposes where this information was available (e.g., in some census datasets) to assess the scale of difference.

\subsection{Identifying Resource Concerns and Impacts on Household Water Supply}

To identify resource concerns, we first undertook a literature review of current and emerging resource concerns. Academic and non-academic literature was identified through targeted searches in Google Scholar and Google's general search engine of 'groundwater' and the name of each case study country. Based on an initial scan of the most pertinent literature, a snowballing approach was used to identify further relevant documents. Advice on relevant documentation was also sought from sector 
experts. Resource sustainability concerns identified from the document review were collated for each country and then considered across countries to build a picture of common themes and key differences.

To identify how groundwater resource concerns impact household services, we used the systems thinking technique of influence diagramming to explore the relationships between types of resource concerns and water services articulated with reference the human right to water. According to the human rights framework, water for personal and domestic uses must be available, safe, acceptable, accessible and affordable [29]. As a clear, comprehensive and globally endorsed conceptualization of household water requirements, the components of the right to water offered a helpful way of exploring the various ways resource issues can affect household water supply. We applied a systems thinking technique as a heuristic for exploring interconnections, given the value of this approach for engaging with complexity, reframing situations and enabling "thinking and acting in purposeful ways" [30]. Within systems thinking, influence diagrams are sense-making tools for exploring the multiple interconnections characteristic of complex systems [31], and represent a mental model of a problematic situation that can help identify actions to improve the situation [32]. They focus on 'influence' rather than causal relationships, and in doing so seek to identify networks of interconnection rather than root causes [31]. As part of broader systems thinking approaches, influence diagrams have been used in resource management to identify interactions between biophysical and 'soft' systems [33].

\subsection{Limitations}

The main limitation of this study relates to the availability and reliability of data on water resources linked to household uses. As described above, it was necessary to compile data from a wide variety of sources with sometimes inconsistent boundaries of analysis, and to make assumptions where information was not available. We addressed concerns about the validity of assumptions by triangulating from multiple information sources and seeking reviews of our draft workings from sector experts. While lack of data reliability is a limitation, it also underpins the value of the study in making a first assessment of household groundwater reliance in contexts where this information is not otherwise available at a national scale.

Across both data collection and literature review methods, the focus was primarily on English language material, which brings a risk of overlooking relevant information in other languages. While some data was sourced and translated through country contacts (for example, utility data for Vietnam and Indonesia), this was not consistently possible. In reviewing the status of groundwater resources, a focus on published English-language material also presents issues of possible bias, with a tendency in the literature to focus on locations within countries where issues have already been observed. This has the potential to obscure geographic diversity within countries, but it was a necessary trade-off in taking a multi-country perspective.

\section{Results}

\subsection{Households Using Groundwater in Case Study Countries}

Across the ten case study countries, an average of $66 \%$ of households in urban areas and $60 \%$ in rural areas were found to be using groundwater as their primary source of drinking water. Urban areas showed lower rates of household groundwater reliance in Cambodia (17\%) and PNG $(25 \%)$ and higher rates in Timor-Leste (93\%), Indonesia (90\%), Kiribati (90\%), Vanuatu (86\%), Lao PDR (80\%) and Myanmar (72\%). In rural areas, we found lower rates of groundwater reliance in Melanesian countries of PNG (22\%), Solomon Islands (28\%) and Vanuatu (34\%) and the highest rate of reliance in the Micronesian atoll islands of Kiribati (95\%). Southeast Asian case study countries Indonesia (92\%), Timor-Leste ( $81 \%$ ) and Myanmar (78\%) were also found to have high rates of rural household groundwater dependence. Findings across all case study countries are summarised in Figure 1, with data sources and assumptions underlying the calculations described in full in Supplementary Materials. 


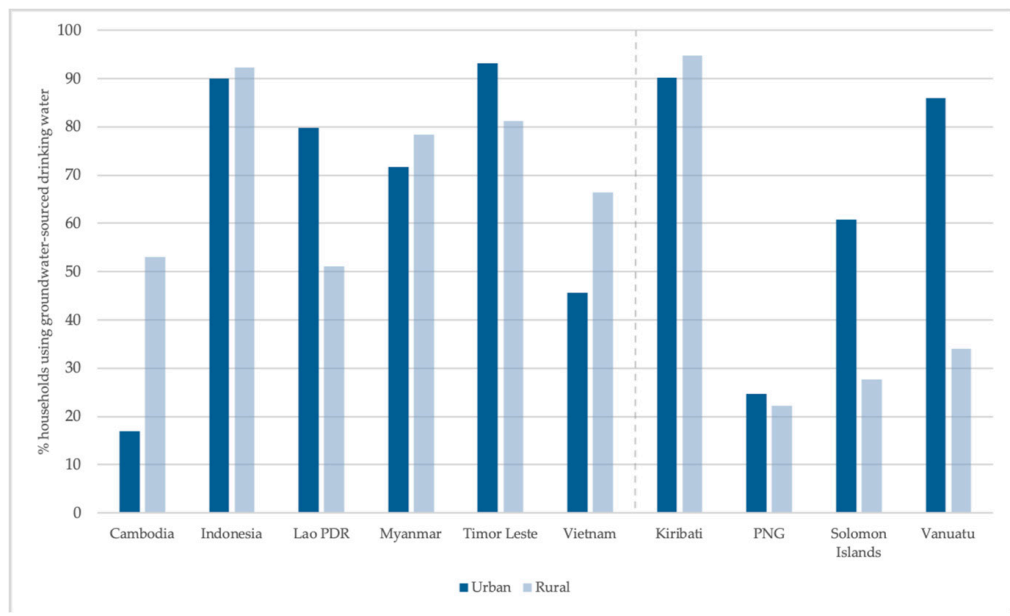

Figure 1. Proportion of households using groundwater as their primary source of drinking water in urban and rural areas across case study countries.

Groundwater-sourced drinking water is supplied to households in case study countries through a mix of point source facilities, piped systems and packaged water. The breakdown of facilities used across urban and rural areas is shown in Table 1 (with data sources and assumptions described in Supplementary Materials). Identifying the resources supplying piped and packaged water was important for urban areas, where the use of point-source groundwater is declining with the increasing use of tap and packaged water $[1,27]$. Case study countries where piped water in urban areas was found to be wholly or substantially drawn from groundwater included Solomon Islands, Vanuatu, Kiribati and Timor-Leste with $94 \%, 68 \%, 67 \%$ and $65 \%$ respectively of urban households using piped water drawn from groundwater sources. Countries where packaged water in urban areas was found to be wholly or substantially drawn from groundwater included Lao PDR, Indonesia and Myanmar, with $64 \%, 46 \%$ and $34 \%$ of households respectively using packaged water sourced from groundwater. In rural areas, point source facilities continue to be the primary form of groundwater supply across the region, and findings, therefore, reflect data on facilities used. Timor-Leste was the only country where piped groundwater (in the form of gravity-fed spring-sourced systems) formed a substantial proportion of piped supplies (38\%). Smaller proportions of households using groundwater-sourced piped water were also identified in Indonesia (6\%), Kiribati $(6 \%)$ and Vietnam (5\%). Packaged water formed part of the mix in rural Lao PDR (21\%), Indonesia (16\%), Vietnam (8\%) and Myanmar (4\%).

Table 1. Proportion of households using point-source, piped and packaged water sourced from groundwater in urban and rural areas.

\begin{tabular}{ccccccccc}
\hline & \multicolumn{3}{c}{$\begin{array}{c}\text { Urban \% Households Using Groundwater- } \\
\text { Sourced Drinking Water }\end{array}$} & \multicolumn{2}{c}{$\begin{array}{c}\text { Rural \% Households Using Groundwater- } \\
\text { Sourced Drinking Water }\end{array}$} \\
\cline { 2 - 9 } & $\begin{array}{c}\text { Point } \\
\text { source }\end{array}$ & Piped & Packaged & $\begin{array}{c}\text { Total } \\
\text { Urban }\end{array}$ & $\begin{array}{c}\text { Point } \\
\text { Source }\end{array}$ & Piped & Packaged & $\begin{array}{c}\text { Total } \\
\text { Rural }\end{array}$ \\
\hline Cambodia & 13 & 4 & 0 & $\mathbf{1 7}$ & 50 & 0 & 0 & $\mathbf{5 0}$ \\
Indonesia & 38 & 6 & 46 & $\mathbf{9 0}$ & 71 & 6 & 16 & $\mathbf{9 2}$ \\
Lao PDR & 13 & 3 & 64 & $\mathbf{8 0}$ & 34 & 0 & 21 & $\mathbf{5 5}$ \\
Myanmar & 34 & 3 & 34 & $\mathbf{7 2}$ & 75 & 0 & 4 & $\mathbf{7 8}$ \\
Timor Leste & 28 & 65 & 0 & $\mathbf{9 3}$ & 43 & 38 & 0 & $\mathbf{8 1}$ \\
Vietnam & 17 & 17 & 12 & $\mathbf{4 6}$ & 53 & 5 & 8 & $\mathbf{6 6}$ \\
Kiribati & 23 & 67 & 0 & $\mathbf{9 0}$ & 89 & 6 & 0 & $\mathbf{9 5}$ \\
PNG & 5 & 20 & 0 & $\mathbf{2 5}$ & 22 & 0 & 0 & $\mathbf{2 2}$ \\
Solomon Is. & 3 & 58 & 0 & $\mathbf{6 1}$ & 28 & 0 & 0 & $\mathbf{2 8}$ \\
Vanuatu & 2 & 83 & 1 & $\mathbf{8 6}$ & 22 & 0 & 0 & $\mathbf{2 2}$ \\
\hline
\end{tabular}

Moving from national proportions to identify numbers of people implicated, the analysis found that $79 \%$ of both urban and rural populations aggregated across case study countries used groundwater as their primary source of drinking water (346 of 437 million people). Figure 2 indicates the relative 
numbers of people drinking groundwater in each case study country and shows the relationship between urban and rural groundwater reliance for each country. Indonesia had the highest groundwater-reliant population (more than 200 million) of the ten countries reviewed, far more than Vietnam (more than 55 million) and Myanmar (more than 40 million) in second and third place respectively. For most case study countries, rates of reliance on groundwater for drinking were reasonably comparable across urban and rural areas, with three notable exceptions: Vanuatu and the Solomon Islands, with much higher rates of urban groundwater reliance, and Cambodia where rural groundwater reliance was almost three times higher than urban. Looking at facilities used to supply groundwater, 219 million of the case study population used groundwater-based point source facilities (66 million in urban areas, 153 million in rural). Groundwater-sourced piped water supplied 25 million (14 million urban, 11 million rural) and groundwater-sourced packaged water supplied 102 million people (76 million urban, 26 million rural).

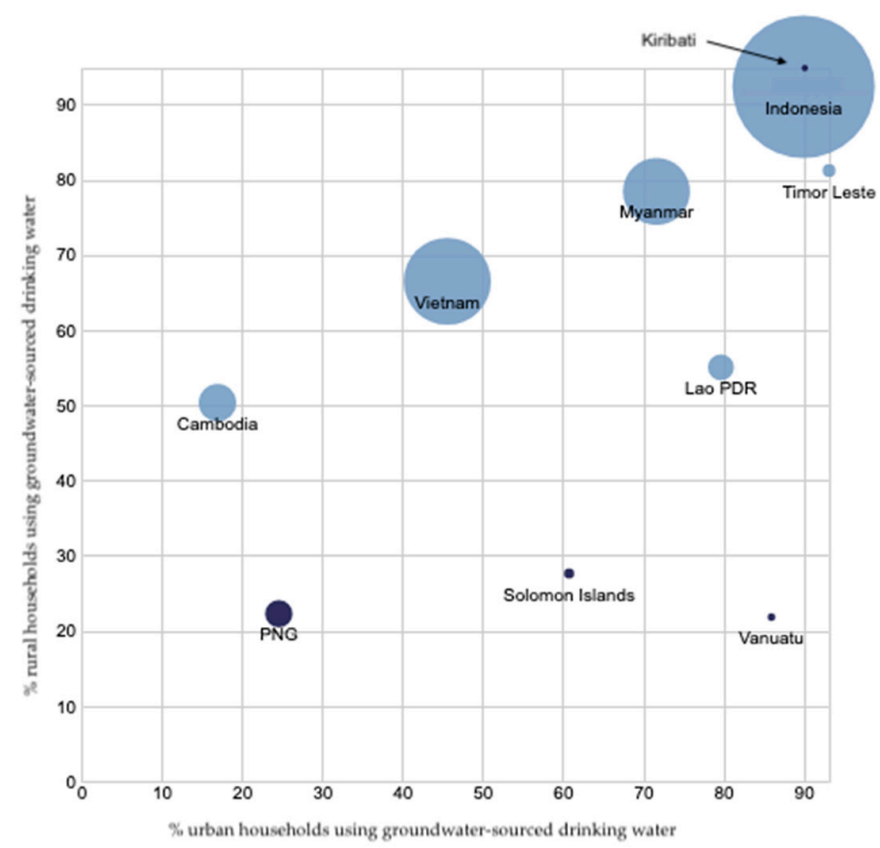

Figure 2. Proportion of urban and rural households using groundwater as their primary source of drinking water with associated relative populations across countries indicated by circle size.

\subsection{Current and Emerging Groundwater Resource Concerns}

Analysis of the context and concerns relating to groundwater resources in case study countries revealed a range of current and emerging issues related to both the quality and quantity of groundwater sources. Table 2 summarises issues identified in the literature for urban and rural areas in each of the ten case study countries. In urban areas, pollution from unsafe sanitation was the most commonly identified threat to groundwater quality in all case study countries. Depletion was an issue for countries with substantial urban groundwater reliance, resulting in dry season shortages in Timor-Leste, Kiribati and Myanmar and subsidence in large cities in Indonesia and Vietnam. In rural areas, hot spots were identified in Cambodia and Lao PDR where drawdown of groundwater levels was affecting accessibility for domestic supplies. Quality concerns in rural areas included saline intrusion in coastal areas (in Cambodia, Timor-Leste, Vietnam and Solomon Islands) and agriculture-related pollution (in Vietnam and Solomon Islands). Uncertainties and future pressures are also noted, with common themes across countries being: A lack of comprehensive data, increasing water demand, and resource risks related to predicted climate change impacts.

Influence diagramming based on this review of current and emerging groundwater resource concerns enabled exploration of the relationship between groundwater resource concerns and the 
components of the human right to water, namely: Availability, quality, affordability, accessibility, and acceptability (Figure 3). In developing the diagram, our main interest was physical characteristics because the focus of the study is the physical aspects of resources and how they influence water services. The effects of a particular relationship depend on the situation. Therefore, the directions of the arrows in Figure 3 should not be taken as indications of positive or negative influences. Further, in line with systems thinking approaches, diagramming was undertaken to increase our understanding of system relationships rather than to reveal a 'truth' [31]. As such, for generating insights, the process of developing the diagram was as important as, or more important than, the diagram itself, which is inevitably a simplified representation of reality. Further, given the intent of this study was to explore the breadth of issues at a regional scale, the diagram represents a generalized model that can guide the scope and focus of local-scale analyses.

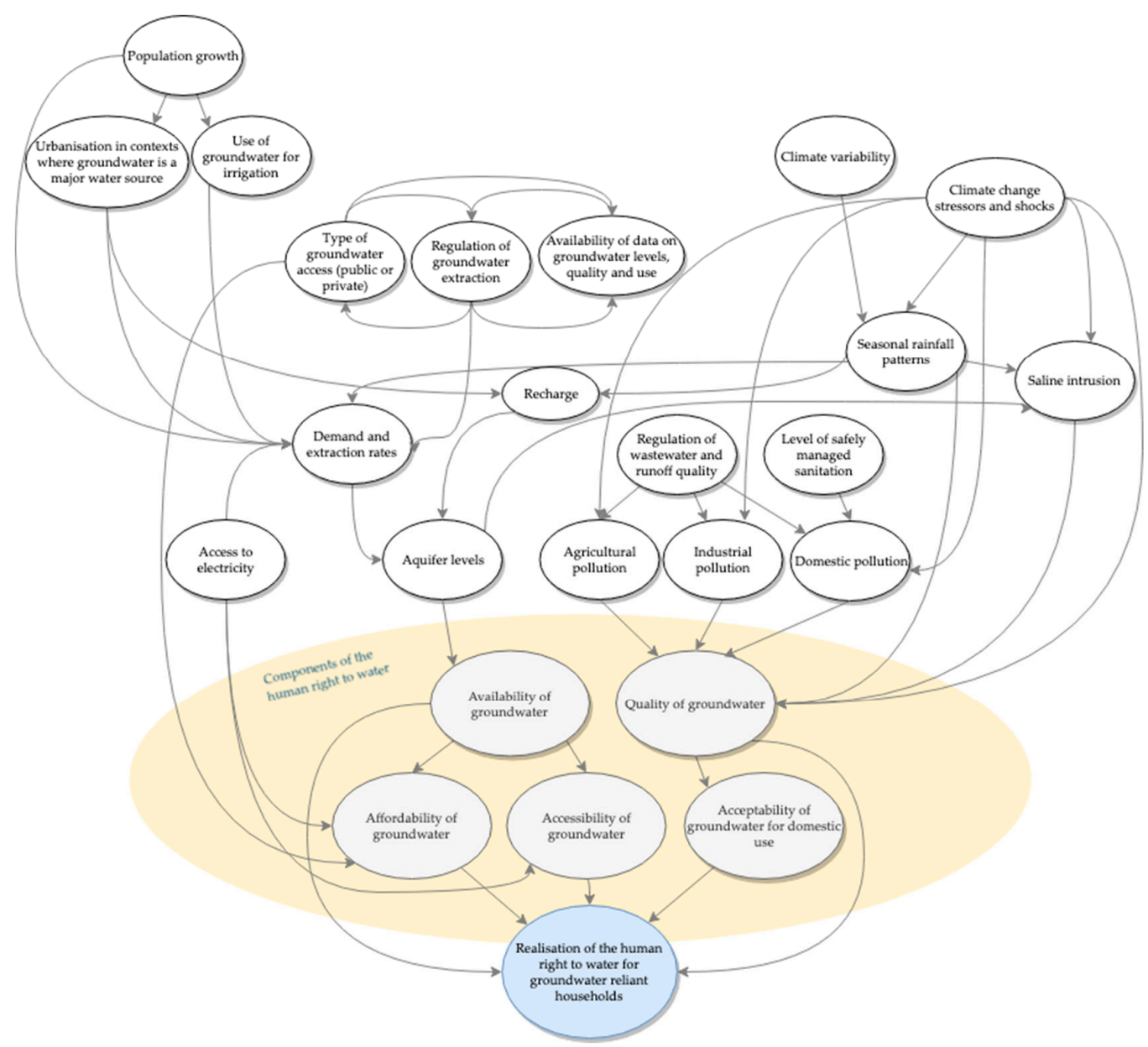

Figure 3. Influence diagram exploring how resource dynamics affect components of the human right to water for groundwater-reliant households. Arrows should be read as 'influences', rather than implying causation. Note that important factors shaping groundwater resources and their access, such as soil type and geology, are held constant, and therefore, not included in the diagram. 
Table 2. Synthesis of literature on groundwater resource concerns in case study countries.

\begin{tabular}{|c|c|c|c|}
\hline & Current Issues in Urban Areas & Current Issues in Rural Areas & Uncertainties and Future Pressures \\
\hline Cambodia & $\begin{array}{l}\text { Urban wastewater pollution has been identified as a } \\
\text { threat to groundwater quality, with studies identifying } \\
\text { bacterial contamination [34]. }\end{array}$ & $\begin{array}{l}\text { Rapid growth in use of groundwater for irrigation in the } \\
\text { Mekong threatens household groundwater use [35]. } \\
\text { Over-extraction may contribute to: Saline intrusion [36], } \\
\text { land subsidence and exacerbation of naturally occurring } \\
\text { arsenic contamination [35]. }\end{array}$ & $\begin{array}{l}\text { Comprehensive data not available but a study is } \\
\text { underway [37]. Cambodia Wellmap database is thought to } \\
\text { lack critical information and be out of date [34]. Threats } \\
\text { include industrial pollution, increasing agricultural use } \\
\text { and saline intrusion [37]. Increased use of agricultural and } \\
\text { domestic electric pumps can increase extraction rates [35]. }\end{array}$ \\
\hline Indonesia & $\begin{array}{l}\text { Over-extraction and pollution are impacting } \\
\text { groundwater across urban Indonesia [38,39]. In Jakarta, } \\
\text { observed issues include pollution from wastewater as } \\
\text { well as flooding, subsidence and salinization in } \\
\text { northern coastal areas [40,41]. In Yogyakarta city, } \\
\text { leaching from on-site sanitation has caused pollution of } \\
\text { drinking water sources [42]. }\end{array}$ & $\begin{array}{l}\text { Much less literature on rural groundwater, likely } \\
\text { reflecting generally fewer resource concerns. One study } \\
\text { in the lowlands of Sumatra found arsenic concentrations } \\
\text { exceeding drinking water guidelines in } 12 \text { of } 97 \\
\text { tubewells [43]. }\end{array}$ & $\begin{array}{l}\text { Self-supply from groundwater for domestic use is } \\
\text { common, though is unregulated [44]. Deep groundwater } \\
\text { resources are increasingly used in industrial and service } \\
\text { sectors and exploited at an unsustainable rate [24]. }\end{array}$ \\
\hline Lao PDR & $\begin{array}{l}\text { Deep wells in Vientiane found to be saline and } \\
\text { unsuitable for domestic use [45]. Sanitation-related } \\
\text { contamination identified, but data is sparse [46]. } \\
\text { Beyond Vientiane, limited information on groundwater } \\
\text { resources in urban areas. }\end{array}$ & $\begin{array}{l}\text { Villages in northern Champassak province have } \\
\text { experienced lowering of water table depths beyond the } \\
\text { reach of average domestic wells [47]. }\end{array}$ & $\begin{array}{l}\text { No serious widespread issues reported, but "preventative } \\
\text { protection" called for due to increasing demand [48]. } \\
\text { Demand will increase due to population growth, changed } \\
\text { agricultural practices [49] and climate change driving } \\
\text { surface water shortages [50]. Limited data available to } \\
\text { support sustainable management [49]. }\end{array}$ \\
\hline Myanmar & $\begin{array}{l}\text { Yangon groundwater experiencing increasing pressure } \\
\text { due to population growth, urbanization and land cover } \\
\text { change. Extraction rates for domestic use alone exceed } \\
\text { recharge [51]. The water is thought to be potable, but } \\
\text { data to confirm quality is lacking and there are reported } \\
\text { cases of tubewells being abandoned due to saline } \\
\text { intrusion [51]. }\end{array}$ & $\begin{array}{l}\text { A study of central Myanmar's Dry Zone [52] reports the } \\
\text { existence of hundreds of thousands of tubewells and } \\
\text { dugwells but there is no database to support monitoring } \\
\text { and management and there is a lack of regulation. } \\
\text { Over-exploitation has resulted in water level drawdown } \\
\text { and deterioration of water quality [52]. }\end{array}$ & $\begin{array}{l}\text { Pavelic et al. explore the potential for groundwater to } \\
\text { support agricultural expansion in the Dry Zone, finding } \\
\text { rates of replenishment lower than expected [53]. Rigorous } \\
\text { assessment of groundwater interventions, and } \\
\text { management that protects groundwater for community } \\
\text { uses and the environment are needed. Climate change } \\
\text { impacts are expected to include a lowering of the shallow } \\
\text { groundwater table and saline intrusion, particularly in } \\
\text { coastal areas [54]. }\end{array}$ \\
\hline $\begin{array}{l}\text { Timor- } \\
\text { Leste }\end{array}$ & $\begin{array}{l}\text { Population growth and urbanization have led to dry } \\
\text { season shortages in Dili aquifer [55]. Shallow aquifers } \\
\text { in urban areas, which are the primary source of water } \\
\text { for households, often receive untreated wastewater [56] } \\
\text { and have been found to commonly contain elevated } \\
\text { concentrations of dissolved solids and microbiological } \\
\text { contaminants [57]. }\end{array}$ & $\begin{array}{l}\text { Groundwater is currently high quality, except where } \\
\text { seawater intrusion is a problem [58], but testing has } \\
\text { revealed bacteriological contamination of unprotected } \\
\text { sources due to animal and domestic waste [56]. }\end{array}$ & $\begin{array}{l}\text { There is a lack of knowledge about groundwater } \\
\text { sustainability, but climate change, reduced water } \\
\text { availability and growing demand are anticipated to } \\
\text { increase pressure on groundwater [58]. Climate change is } \\
\text { expected to lead to saline intrusion in coastal centers [56]. } \\
\text { There is a lack of information about the density of } \\
\text { boreholes and volumes of water extracted in urban areas, } \\
\text { though their use is expected to grow due to } \\
\text { underperforming piped water services [56]. }\end{array}$ \\
\hline
\end{tabular}


Table 2. Cont

\begin{tabular}{|c|c|c|c|}
\hline & Current Issues in Urban Areas & Current Issues in Rural Areas & Uncertainties and Future Pressures \\
\hline Vietnam & $\begin{array}{l}\text { Aquifers supplying Hanoi and Ho Chi Minh City are } \\
\text { considered to be over-exploited and polluted [59,60] } \\
\text { and in Ho Chi Minh City extraction rates are reportedly } \\
\text { five times higher than recharge [61]. Groundwater } \\
\text { levels in Can Tho City in the Mekong Delta are } \\
\text { dropping by up to half a meter each year [62]. }\end{array}$ & $\begin{array}{l}\text { Shallow groundwater resources in the Mekong are } \\
\text { characterized by salinization and pollution (likely due to } \\
\text { domestic wastewater), causing increased exploitation of } \\
\text { deeper aquifers (up to } 400-50 \mathrm{~m} \text { ) [62]. Indications of } \\
\text { contamination from pesticides: } 5 \text { of } 22 \text { groundwater } \\
\text { samples in Mekong Delta found to contain levels } \\
\text { exceeding European Commission recommended } \\
\text { concentrations [63]. }\end{array}$ & $\begin{array}{l}\text { The impacts of climate change on groundwater are } \\
\text { uncertain. Modeling for a coastal aquifer in central } \\
\text { Vietnam projected a decrease in groundwater resources, } \\
\text { contrary to assumptions that increased rain would result } \\
\text { in increased recharge [64]. Reductions in recharge in the } \\
\text { short, medium and longer term have also been projected in } \\
\text { the Mekong Delta, with a resultant decline in groundwater } \\
\text { levels and storage [65]. }\end{array}$ \\
\hline Kiribati & $\begin{array}{l}\text { A study of the freshwater lens on Bonriki Island [66] } \\
\text { found pumping is causing sustained contraction. } \\
\text { Pollution of shallow freshwater lenses under human } \\
\text { settlements is a serious concern given shallow } \\
\text { permeable soils and short travel times to the water table, } \\
\text { with the result that groundwater in large areas of urban } \\
\text { Tarawa is no longer potable [67]. }\end{array}$ & $\begin{array}{l}\text { Studies on outer islands have found E. coli bacteria in } \\
\text { more than } 90 \% \text { of sampled wells, related to proximity to } \\
\text { toilets and other sources of contamination }[68,69] .\end{array}$ & $\begin{array}{l}\text { Kiribati extremely vulnerable to climate change due to its } \\
\text { low average altitude ( } 2 \mathrm{~m} \text { above sea level). Quantity and } \\
\text { quality of groundwater is likely to be affected by both } \\
\text { variations in rainfall and sea level rise [70]. A regional } \\
\text { vulnerability assessment of Pacific Island groundwater } \\
\text { and future climates [71] found Kiribati is one of three } \\
\text { countries with the greatest number of islands most } \\
\text { vulnerable to low rainfall. }\end{array}$ \\
\hline $\begin{array}{l}\text { Papua } \\
\text { New } \\
\text { Guinea }\end{array}$ & $\begin{array}{l}\text { Monitoring of groundwater very poor and little is } \\
\text { known about the situation in many provincial towns } \\
\text { and almost all district towns [72]. Contamination from } \\
\text { onsite wastewater systems is a concern for urban } \\
\text { centers where groundwater is the source of utility } \\
\text { supplies including Lae, Kimbe and Kavieng [73]. }\end{array}$ & $\begin{array}{l}\text { Groundwater still considered to be the safest and most } \\
\text { reliable source of water, and is the only reliable source on } \\
\text { outer islands and in mainland coastal communities [74]. }\end{array}$ & $\begin{array}{l}\text { PNG has abundant surface water resources (hence lower } \\
\text { household groundwater reliance) and groundwater } \\
\text { resources have not yet been developed at scale. However, } \\
\text { there is evidence that groundwater is increasingly being } \\
\text { used due to its high quality and reliability [75]. Changing } \\
\text { agricultural practices and the increasing use of artificial } \\
\text { fertilizers, pesticides, herbicides and palm oil mill effluent } \\
\text { (for irrigation) pose a threat to groundwater and surface } \\
\text { water quality [73]. }\end{array}$ \\
\hline $\begin{array}{l}\text { Solomon } \\
\text { Islands }\end{array}$ & $\begin{array}{l}\text { Poor sanitation has led to suspected cases of } \\
\text { groundwater contamination in Honiara, and pollution } \\
\text { is driving a shift from groundwater to rainwater [76]. } \\
\text { Contamination of groundwater from sewage outfalls, } \\
\text { septic tanks, unserved informal settlements and a } \\
\text { septage disposal facility has also been reported [77]. }\end{array}$ & $\begin{array}{l}\text { Salinization of groundwater is increasing in coastal } \\
\text { villages and atoll islands due to sea water intrusion } \\
\text { during extreme weather events or as a general trend) } \\
\text { [78]. Quality of ground-water and surface water } \\
\text { threatened by chemicals and fertilizers used for palm oil } \\
\text { development on Guadalcanal plains [79]. }\end{array}$ & $\begin{array}{l}\text { An assessment of Pacific Is. groundwater and future } \\
\text { climates [71] found Solomon Is. to be one of three } \\
\text { countries with the greatest number of islands most } \\
\text { vulnerable to low rainfall, and one of three countries with } \\
\text { the greatest number of islands most vulnerable to mean } \\
\text { sea-level rise. As well as sea level rise, residential } \\
\text { development and mining have been identified as future } \\
\text { threats to groundwater quality [74]. }\end{array}$ \\
\hline Vanuatu & $\begin{array}{l}\text { Groundwater quality in Port Vila and Luganville } \\
\text { generally good, but poor sanitation is an acknowledged } \\
\text { threat and groundwater levels are decreasing while } \\
\text { pumping is increasing [78]. }\end{array}$ & $\begin{array}{l}\text { No concerns evident in literature, and a study across } 10 \\
\text { islands found groundwater to be a safer source than } \\
\text { rainwater in microbial terms [80]. }\end{array}$ & $\begin{array}{l}\text { A comprehensive and accurate database of the quality, } \\
\text { quantity and location of water resources does not yet } \\
\text { exist [81]. Increasing use of motorized pumps [80] may } \\
\text { impact extraction volumes. }\end{array}$ \\
\hline
\end{tabular}


The process of developing the influence diagram generated three material insights about the groundwater resource situation and how it affects water service delivery. Firstly, data availability, regulation of groundwater extraction and type of groundwater access are highly interconnected, and therefore, warrant particular consideration. Across the case study countries, poor data was identified as a critical gap that prevents effective resource management and regulation. The type of groundwater access is pivotal in this picture, with household self-supply or service provider access and commercial access (e.g., for packaged water) presenting different challenges for monitoring and regulation compared with publicly managed systems. Secondly, influences on groundwater quality arise from domestic, agricultural, industrial and natural processes, indicating the need for a cross-sectoral approach to addressing quality concerns. Thirdly, climate-related pressures arising from natural variability and climate change emerged as being connected with many other system processes, and they, therefore, demand attention with a view to building resilience for households relying on groundwater for drinking.

\section{Discussion}

The two bodies of information explored in this study-household reliance on groundwater for drinking supplies and groundwater resource concerns-are both foundational for sustainable water service delivery. Bringing these analyses together, this discussion explores implications for WASH professionals across three themes of (i) data gaps and monitoring, (ii) regulatory priorities for sustainable services, and (iii) building resilience to emerging threats. Points raised in this discussion reflect an inductive analytical approach, with a focus on those insights most relevant to WASH sector scholars and practitioners. As such, the focus was on interpreting the findings to inform how water services are conceptualized, planned and managed. We also note that although pollution from unsafe sanitation emerged as a common threat to groundwater resources across case study countries, there is substantial ongoing work in the WASH sector focused on progressing safe sanitation [82,83], so we focus this discussion on other implications from the analysis. To contextualize the discussion within current WASH sector framing, where relevant, we draw on the service delivery approach framework of three institutional levels $[18,19]$ to identify implications for national WASH agencies, service authorities and service providers.

\subsection{Data Gaps and Monitoring}

Situating findings from this analysis with reference to academic literature revealed limited research addressing rates of groundwater use for drinking, with available figures often presented as background information rather than empirical findings. The overall proportion of the aggregated population from case study countries found to be using groundwater for drinking $(79 \%)$ is higher than figures reported in the literature, which estimate half of the global population to be reliant on groundwater for drinking $[2,5,6,84]$. Regional studies estimate that a third of all people in Asia rely on groundwater for drinking $[85,86]$. This is substantially different from the $79 \%$ found to be groundwater-reliant across case study countries in this paper. Other than the abovementioned global and regional estimates, there is limited research addressing rates of groundwater use for drinking [6]. This makes it challenging to benchmark findings and situate case study countries within a broader set, highlighting a need for further research to validate the initial estimates presented in this paper and to extend geographic reach.

In urban areas, global monitoring data indicates a trend away from the use of point source facilities to greater use of piped and packaged water [1,27], with a consequent increasing knowledge gap in standardized monitoring about which water resources are used in those cases. Foster et al. [14] estimate that more than 1.5 billion urban dwellers worldwide currently rely on groundwater, which represents more than three-quarters of the global urban population. Comparable rates of urban reliance were also identified in this study. However, systematic, comprehensive and reliable data is acknowledged to be lacking $[14,87]$ and further work is needed to validate both total estimates of urban groundwater reliance and how these reflect diversity across and within countries. This is 
important given that groundwater use in cities is forecast to increase due to the pressures of population growth, increasing per capita water use, reduced surface water security (related to climate change) and higher ambient temperatures [14]. Improving our understanding of the extent to which groundwater resources are relied upon is particularly critical for small towns and urbanizing rural centers, where authorities are faced with complex planning challenges and professionalized utilities have not yet established [88]. Studies in Africa identify a need for urban water suppliers to better coordinate with agencies responsible for groundwater resource management [89,90]. In Southeast Asian and Pacific countries, urban water service providers and authorities could similarly play a more active role in debates and planning for sustainable groundwater resource management.

For WASH sector professionals, particularly at the national level, there is a need to collate information about the groundwater resource implications of packaged water given its status as a growing source of drinking water [27] including in countries reviewed in this study (particularly in Lao PDR, Indonesia, Myanmar and Vietnam). While studies have explored the public health implications of packaged drinking water [91], its classification within global monitoring standards [27], and equity and power dynamics [92], sustainability implications have received only limited attention and focused on plastic waste $[93,94]$ rather than on the relevant water resources. In this study, when compiling figures on groundwater use, packaged water was typically the most difficult form of use to identify and quantify. More systematic and rigorous research into the sources and distribution of packaged water is needed to track what is emerging to be an important part of the global water supply picture. Taking an equity perspective will be critical, given that the resources supplying packaged water can be distant from the locations where it is consumed, and given that the associated risks and benefits can also be widely distributed across different populations.

The use of multiple water sources for different household uses is another critical consideration for understanding groundwater use, given that drinking water is just one (albeit critical) form of household water use. Households in low and middle income countries commonly obtain water from a range of sources, as evidenced by a growing body of literature on multiple water source use (MWSU) [28,80]. In our case study countries, where data allowed, we investigated sources of water used for drinking and for other domestic purposes to assess how this might affect interpretations of groundwater use. In some cases, for example, in countries where the use of packaged water for drinking was high (Lao PDR, Myanmar, Indonesia), the volume of groundwater used was less than the volumes of other domestic sources (e.g., tap water was sourced from a mix of surface and groundwater). In other cases, we found that if we based our analysis on primary drinking sources alone, we were likely to underestimate the importance of groundwater. In rural Vanuatu, for example, a 2016 census included questions on both main and alternative drinking sources. The use of groundwater was found to be substantially greater (by a factor of three) when the use of groundwater as a secondary source was included [95]. In Lao PDR, a study of rural household groundwater use found that some households used point-source groundwater for non-drinking domestic purposes in situations where reticulated water was used for drinking [96]. In atoll islands of the Solomon Islands, an analysis of water resources management found that groundwater is used for washing but not drinking [73]. In Indonesia, anecdotal evidence suggests households use bottled water for cooking as well as drinking and piped water for washing and cleaning [97], which aligns with MWSU research indicating a positive correlation between sources of water for consumptive and non-consumptive uses [98]. In future work looking at groundwater use, it will be important to consider the MSWU picture, and build on the growing empirical research in this area.

Moving from groundwater use to resource management, a lack of sufficient data to inform appropriate groundwater management was identified across case study countries, reflecting a region-wide gap in groundwater monitoring systems and data [99]. With data and information acknowledged to be critical for effective groundwater governance [15], there is an urgent need to invest in monitoring and improve the quantity and quality of groundwater information, including through approaches such as remote sensing [99]. For the WASH sector, there is an opportunity for service 
authorities and providers to play a direct role monitoring the resources on which they rely, and to proactively coordinate (for information sharing and strategy development) with agencies responsible for groundwater resource management.

\subsection{Regulatory Priorities for Sustainable Services}

Informed by the analysis of groundwater use, resource concerns and system interactions, we identify regulatory priorities for the WASH sector relating to self-supply situations, monitoring and management of service providers, and agricultural groundwater extraction. These respond to acknowledged data gaps (as discussed above) and interconnections between data availability, type of groundwater access (public or private) and regulation of abstraction (as identified in systems diagramming).

In the WASH sector, self-supply is seen as a viable strategy for accelerating access to safely managed water when treated, and supported, as a formal service delivery model $[19,100,101]$. However, risks have been identified for groundwater-sourced systems, including the potential for privately-financed wells used for both drinking and productive activities to result in a drawdown of groundwater levels [100], and the invisibility of abstraction from, and potential pollution of, aquifers [89]. Much of the documented experience with supported self-supply has focused on Africa and South Asia [102], and there is a need to explore how research to date relates to Southeast Asian and Pacific contexts. In case study countries where the proportion of households using point-source groundwater was high, studies have reported regulatory challenges because access of this type is commonly on-plot, self-financed and difficult to monitor. For example, research in Vietnam's Can Tho Province found that much more of the groundwater used by households came from private shallow tube-wells than from utility-managed groundwater plants [62]. In Indonesia's capital Jakarta, unregistered private abstraction continues apace despite the institution of regulatory approaches, such as differential tariffs over the past 20 years [40]. Self-supply is also widespread in rural Cambodia: Of more than 35,000 groundwater point sources included in the WellMap database that include ownership information, $83 \%$ are described as 'private', increasing to $91 \%$ in areas with elevated arsenic. Although self-supplied water services are (by definition) managed by individual households, responses from both national agencies and service authorities are still needed to ensure the safety and sustainability of groundwater-based self-supply systems.

Second, regulatory frameworks must evolve to ensure adequate monitoring and management of those abstracting and supplying groundwater to safeguard against unsustainable abstraction and use. One example is the case of private sector providers, which have particular incentives to maximize volumes of water sold. Small-scale private water suppliers are increasingly supported by development agencies [103] and some governments, such as in Vietnam [104] and Cambodia [105]. Research in Vietnam found private water providers in rural areas seeking to increase customer demand for water as a strategy to improve business viability, but without consideration of sustainable abstraction rates [104]. These issues are not only relevant to private providers and monitoring and regulation are critical irrespective of service delivery model. For example, a study in Indonesia's coastal city of Semarang identified a need for policy and tariff structures that promote groundwater conservation given the prevalence of community-based providers supplying artesian water (under both commercial and non-commercial models) [106]. Water service delivery agencies, particularly at the service authority level, can play a role monitoring and regulating the operations of service providers, including ensuring coordination with regulatory requirements for abstraction which may be separately governed by water resource agencies.

Third, it is important that agricultural groundwater use is regulated to ensure that domestic supplies are protected. This is evidenced by the situation in south-eastern Cambodia, where rapidly increasing abstraction for irrigation threatens to make groundwater inaccessible to standard household pumps within fifteen years [35]. A regulatory response involving the preservation of groundwater for low-volume, high-priority uses (such as domestic supply) and ensuring agricultural development is 
shaped by available surface water supplies has been proposed [35]. Calls to preserve groundwater for domestic uses and replace other uses with surface water wherever possible have also been made with reference to Lao PDR [49] and Vietnam [62]. While agricultural groundwater use is not within the purview of ministries governing water services delivery, WASH agencies can proactively advocate for prioritization of domestic supplies within water allocation planning at national and sub-national scales.

\subsection{Building Resilience to Emerging Threats}

Groundwater threats arising from climate variability and climate change were commonly identified in the literature across reviewed countries, indicating a need to strengthen the resilience of groundwater-supplied households. Particular concerns were raised in the climate-vulnerable Pacific Islands of Kiribati and Solomon Islands [71] and coastal areas in Southeast Asia in Myanmar [54], Timor-Leste [56] and Vietnam [64,65]. Compared with other water resources, groundwater is considered less likely to be affected by climate change and it is, therefore, believed to be positioned to form the basis of adaptation programs [3]. However there remains considerable uncertainty about the actual relationship between groundwater and climate [107], and the resilience of groundwater-sourced household supplies to climate-related hazards varies depending on aquifer depth and the quality of system construction $[108,109]$. Further, climate-related pressures can indirectly affect groundwater, as revealed in diagramming conducted in this study. For example, a shift in demand away from climate-affected water sources to more resilient groundwater sources can ultimately influence aquifer levels. Taylor et al. [107] identify this threat of overexploitation, forecasting rises in groundwater abstraction in absolute terms and as a proportion of total water withdrawals. For WASH institutions, strategies which rely on groundwater as the basis of adaptation pathways need to be carefully considered in context, along with broader approaches to building resilience, such as being identified in both urban and rural WASH literature [110,111].

A final consideration relates to emerging contaminants and their potential to pollute groundwater sources that supply drinking water. Pollution from greywater or agricultural and industrial sectors was not a strong theme in the reviewed literature, with only three countries (Vietnam, Papua New Guinea and Solomon Islands) identifying particular areas affected by pesticide and fertilizer contamination $[63,73,79]$. However, this area requires attention, given monitoring systems are poorly equipped to identify the expanding range of contaminants and their impacts $[5,112,113]$. Global reviews have found groundwater pollution at environmentally significant concentrations from a range of pharmaceutical and personal care products (PPCPs), industrial compounds and lifestyle compounds, such as caffeine [112,113]. PPCPs have been found to be difficult to remove from groundwater, indicating a need to control their release from the source [112]. There are implications here for WASH institutions at all levels, with a need for leadership at the national level to ensure emerging contaminants are on the agenda in cross-sectoral forums and inform future service delivery frameworks governing groundwater-based systems.

\section{Conclusions}

This study has established a baseline of populations using groundwater for drinking in ten Southeast Asian and Pacific nations and identified the breadth of resource issues that must be considered, analyzed and planned for as part of efforts to expand and sustain water services. The results of this study confirm groundwater to be a critical source of drinking water for households in case study countries, with comparable rates of households using groundwater as their primary source of drinking water in urban $(66 \%)$ and rural $(60 \%)$ areas. Our findings point to higher rates of reliance than commonly reported in the literature, with $79 \%$ of the total population across case study countries found to be drinking groundwater. Our review of literature on groundwater resource concerns across case study countries found common concerns related to: Pollution from unsafe sanitation, depletion leading to dry season shortages and subsidence, and both vulnerabilities and uncertainties about future climate-related pressures and threats. 
Systems diagramming provided insight on the relationships between resource concerns and household water services, which generated implications relevant to WASH institutions at national, service authority and service provider levels. These include priorities for further data collation and analysis, a need to review regulatory approaches that address different models of groundwater-based service provision (including both private and public), and considerations for strengthening the resilience of water services.

In taking a multi-country approach, this paper provides comparative data and captures the diversity of experiences, identifying resource themes and building a generalized model of system interactions. This can inform global and local action and advocacy around the risks and concerns raised, as well as inform the scope and focus of future studies within relevant countries at local scales. These can, in turn, underpin strengthened engagement in groundwater resource management by those involved in water service delivery, and ultimately strengthen the sustainability of groundwater-based water services.

Supplementary Materials: The following is available online at http://www.mdpi.com/2073-4441/11/8/1605/s1, Appendix A Data sources and assumptions for groundwater use calculations.

Author Contributions: Conceptualization, N.C., T.F. and J.W.; data curation, N.C.; formal analysis, N.C.; investigation, N.C. and T.F.; methodology, N.C., T.F. and J.W.; project administration, N.C.; supervision, T.F. and J.W.; validation, N.C., T.F. and J.W.; visualization, N.C.; writing-original draft, N.C.; writing-review \& editing, T.F. and J.W.

Funding: This research received no external funding.

Acknowledgments: The authors would like to acknowledge technical input provided by Matthew Bond, Joanne Chong, H Hendarmawan, Khykeng Hor, Khin Kay Khaing, Kyaw Nyunt Linn, Leila Macadam, Giang Nam, Kate Neely, Trevor Nott, Rogelio Ocampo and Shaun Kies-Ryan.

Conflicts of Interest: The authors declare no conflict of interest.

\section{References}

1. WHO/UNICEF. Progress on Drinking Water, Sanitation and Hygiene: 2017 Update and SDG Baselines. 2017. Available online: https://www.who.int/mediacentre/news/releases/2017/launch-version-report-jmp-watersanitation-hygiene.pdf (accessed on 14 December 2018).

2. Velis, M.; Conti, K.I.; Biermann, F. Groundwater and human development: Synergies and trade-offs within the context of the sustainable development goals. Sustain. Sci. 2017, 12, 1007-1017. [CrossRef]

3. Howard, G.; Calow, R.; Macdonald, A.; Bartram, J. Climate change and water and sanitation: Likely impacts and emerging trends for action. Annu. Rev. Environ. Resour. 2016, 41, 253-276. [CrossRef]

4. Guppy, L.; Uyttendaele, P.; Villholth, K.G.; Smakhtin, V. Groundwater and Sustainable Development Goals: Analysis of Interlinkages; UNU-INWEH Report Series, Issue 04; United Nations University Institute for Water; Environment and Health: Hamilton, ON, Canada, 2018.

5. Margat, J.; van der Gun, J. Groundwater Around the World: A Geographic Synopsis; CRC Press Taylor \& Francis Group: Boca Raton, FL, USA, 2013; 376p.

6. Giordano, M. Global Groundwater? Issues and Solutions. Annu. Rev. Environ. Resour. 2009, 34, $153-178$. [CrossRef]

7. Molle, F.; López-Gunn, E.; Van Steenbergen, F. The local and national politics of groundwater overexploitation. Water Altern. 2018, 11, 445-457.

8. Foster, S.; Chilton, J.; Nijsten, G.; Richts, A. Groundwater-A global focus on the 'local resource'. Curr. Opin. Environ. Sustain. 2013, 5, 685-695. [CrossRef]

9. Gleeson, T.; Wada, Y.; Bierkens, M.F.P.; van Beek, L.P.H. Water balance of global aquifers revealed by groundwater footprint. Nature 2012, 488, 197-200. [CrossRef] [PubMed]

10. Steffen, W.; Richardson, K.; Rockstrom, J.; Cornell, S.E.; Fetzer, I.; Bennett, E.M.; Biggs, R.; Carpenter, S.R.; de Vries, W.; de Wit, C.A.; et al. Planetary boundaries: Guiding human development on a changing planet. Science 2015, 347. [CrossRef] [PubMed]

11. Bogardi, J.J.; Fekete, B.M.; Vörösmarty, C.J. Planetary boundaries revisited: A view through the "water lens". Curr. Opin. Environ. Sustain. 2013, 5, 581-589. [CrossRef] 
12. Bradley, D.D.J.; Bartram, J.K.J. Domestic water and sanitation as water security: Monitoring, concepts and strategy. Philos. Trans. A. Math. Phys. Eng. Sci. 2013, 371, 20120420. [CrossRef]

13. Carrard, N.; Willetts, J. Environmentally sustainable WASH? Current discourse, planetary boundaries and future directions. J. Water Sanit. Hyg. Dev. 2017, 7, 209-228. [CrossRef]

14. Foster, S.; Hirata, R.; Misra, S.; Garduño, H. Sustainable Groundwater Management: Contributions to Policy Promotion. In Urban Groundwater Use Policy: Balancing Benefits and Risks in Developing Nations 2010; The World Bank: Washinton, DC, USA, 2010; Available online: http://documents.worldbank.org/curated/en/471001468159609056/Urban-groundwater-use-policybalancing-the-benefits-and-risks-in-developing-nations (accessed on 14 December 2018).

15. Megdal, S.B. Invisible water: The importance of good groundwater governance and management. NPJ Clean Water 2018, 1, 15. [CrossRef]

16. Hadwen, W.L.; Powell, B.; MacDonald, M.C.; Elliott, M.; Chan, T.; Gernjak, W.; Aalbersberg, W.G.L. Putting WASH in the water cycle: Climate change, water resources and the future of water, sanitation and hygiene challenges in Pacific Island Countries. J. Water Sanit. Hyg. Dev. 2015, 5, 183-191. [CrossRef]

17. UN Water/WHO Global Analysis and Assessment of Sanitation and Drinking-Water (GLAAS) 2018/2019 Informational Modules: Introduction to GLAAS. Available online: https://www.who.int/water_sanitation_ health/monitoring/investments/module1-introduction-to-glaas-2018.pdf (accessed on 19 May 2019).

18. World Bank. Sustainability Assessment of Rural Water Service Delivery Models: Findings of a Multi-Country Review; World Bank: Washington, DC, USA, 2017.

19. Moriarty, P.; Smits, S.; Butterworth, J.; Franceys, R. Trends in rural water supply: Towards a service delivery approach. Water Altern. 2013, 6, 329-349.

20. Brikké, F.; Vairavamoorthy, K. Managing Change to Implement Integrated Urban Water Management in African Cities. Aquat. Procedia 2016, 6, 3-14. [CrossRef]

21. Barron, N.J.; Kuller, M.; Yasmin, T.; Castonguay, A.C.; Copa, V.; Duncan-Horner, E.; Gimelli, F.M.; Jamali, B.; Nielsen, J.S.; Ng, K.; et al. Towards water sensitive cities in Asia: An interdisciplinary journey. Water Sci. Technol. 2017, 76, 1150-1157. [CrossRef] [PubMed]

22. Bichai, F.; Cabrera Flamini, A. The Water-Sensitive City: Implications of an urban water management paradigm and its globalization. Wiley Interdiscip. Rev. Water 2018, 5, e1276. [CrossRef]

23. WWAP (United Nations World Water Assessment Programme)/UN-Water. The United Nations World Water Development Report 2018: Nature-Based Solutions for Water; UNESCO: Paris, France, 2018.

24. International Water Association. Principles for Water Wise Cities, 2nd ed.; International Water Association: London, UK, 2016; Available online: https://iwa-network.org/wp-content/uploads/2016/08/IWA_Brochure_ Water_Wise_Cities.pdf (accessed on 19 May 2019).

25. Howard, K.W.F. Sustainable cities and the groundwater governance challenge. Environ. Earth Sci. 2015, 73, 2543-2554. [CrossRef]

26. Foster, S.; Sage, R. Groundwater science in water-utility operations: Global reflections on current status and future needs. Hydrogeol. J. 2017, 25, 1233-1236. [CrossRef]

27. Vedachalam, S.; MacDonald, L.H.; Omoluabi, E.; OlaOlorun, F.; Otupiri, E.; Schwab, K.J. The role of packaged water in meeting global targets on improved water access. J. Water Sanit. Hyg. Dev. 2017, 7, 369-377. [CrossRef]

28. Elliott, M.; Foster, T.; MacDonald, M.C.; Harris, A.R.; Schwab, K.J.; Hadwen, W.L. Addressing how multiple household water sources and uses build water resilience and support sustainable development. NPJ Clean Water 2019, 2. [CrossRef]

29. UN Special Rapporteur on the Human Right to Safe Drinking Water and Sanitation. In Realising the Human Rights to Water and Sanitation: A Handbook by the UN Special Rapporteur; Office of the United Nations High Commissioner for Human Rights: Geneva, Switzerland, 2014; Available online: https: //www.ohchr.org/en/issues/waterandsanitation/srwater/pages/handbook.aspx (accessed on 19 May 2019).

30. Huutoniemi, K.; Willamo, R. Thinking Outward: Heuristics for Systemic Understanding of Environmental Problems. In Transdisciplinary Sustainability Studies: A Heuristic Approach; Huutoniemi, K., Tapio, P., Eds.; Routledge: New York, NY, USA, 2014; pp. 23-49.

31. Armson, R. Growing wings on the way: Systems thinking for messy situations; Triarchy Press: Devon, UK, 2011; 338p. 
32. Checkland, P.; Poulter, J. Soft Systems Methodology. In Systems Approaches to Managing Change: A Practical Guide; Reynolds, M., Holwell, S., Eds.; Springer-Verlag: London, UK, 2010; pp. 191-242.

33. Bosch, O.J.H.; King, C.A.; Herbohn, J.L.; Russell, I.W.; Smith, C.S. Getting the big picture in natural resource management-Systems thinking as 'method' for scientists, policy makers and other stakeholders. Syst. Res. Behav. Sci. 2007, 24, 217-232. [CrossRef]

34. AEC. Water Infrastructure Study: Rapid Assessment of Existing Groundwater Studies and Groundwater Use in Cambodia; Advancing Engineering Consultants: Phnom Penh, Cambodia, 2016.

35. Erban, L.E.; Gorelick, S.M. Closing the irrigation deficit in Cambodia: Implications for transboundary impacts on groundwater and Mekong River flow. J. Hydrol. 2016, 535, 85-92. [CrossRef]

36. WaterAid/British Geological Survey. Groundwater Quality: Cambodia; British Geological Survey: London, UK, 2016; Available online: http://www.bgs.ac.uk/downloads/start.cfm?id=3346 (accessed on 16 August 2018).

37. Sophally, S. Groundwater Resources in Cambodia. Institute for Global Environmental Strategies: Japan. 2011. Available online: https://www.iges.or.jp/en/natural-resource/groundwater/PDF/activity20110602/S1-3_ Mr.Sok-Sophally_GW_Cambodia.pdf (accessed on 16 August 2018).

38. Asian Development Bank. Indonesia Country Water Assessment; Asian Development Bank: Mandaluyong, Philippines, 2016; ISBN 978-92-9257-360-7.

39. Tirtomihardjo, H. Groundwater basins in Indonesia and their potency. In Proceedings of the Asia Pacific Water Forum (APWF) Regional Water Knowledge Hub for Groundwater Management Launch Meeting, Bankok, Thailand, 2-3 June 2011.

40. Furlong, K.; Kooy, M. Worlding water supply: Thinking beyond the network in Jakarta. Int. J. Urban Reg. Res. 2017, 41, 888-903. [CrossRef]

41. Shaad, K.; Burlando, P. Monitoring and modelling of shallow groundwater dynamics in urban context: The case study of Jakarta. J. Hydrol. 2018, in press. [CrossRef]

42. Cronin, A.A.; Odagiri, M.; Arsyad, B.; Nuryetty, M.T.; Amannullah, G.; Santoso, H.; Darundiyah, K.; Nasution, N.A. Piloting water quality testing coupled with a national socioeconomic survey in Yogyakarta province, Indonesia, towards tracking of Sustainable Development Goal 6. Int. J. Hyg. Environ. Health 2017, 220, 1141-1151. [CrossRef] [PubMed]

43. Winkel, L.; Berg, M.; Stengel, C.; Rosenberg, T. Hydrogeological survey assessing arsenic and other groundwater contaminants in the lowlands of Sumatra, Indonesia. Appl. Geochem. 2008, 23, 3019-3028. [CrossRef]

44. Hadipuro, W. Indonesia's water supply regulatory framework: Between commercialisation and public service? Water Altern. 2010, 3, 475-491.

45. JICA. The Lao People's Democratic Republic the Preparatory Survey on Vientiane Capital Water Supply Expansion Project Final Report; Japan International Cooperation Agency (JICA): Tokyo, Japan, 2015.

46. Noda, K.; Makino, T.; Kimura, M.; Douangsavanh, S.; Keokhamphui, K.; Hamada, H.; Iida, T.; Oki, K. Domestic water availability in Vientiane, Lao PDR. J. Agric. Meteorol. 2017, 73, 45-50. [CrossRef]

47. Vote, C.; Eberbach, P.; Zeleke, K.; Inthavong, T.; Lampayan, R.; Vongthilath, S. The use of groundwater as an alternative water source for agricultural production in southern Lao PDR and the implications for policymakers. In A Policy Dialogue on Rice Futures: Rice-Based Farming Systems Research in the Mekong Region, Phnom Penh, Cambodia, 7-9 May 2014; ACIAR Proceeedings No. 142; Australian Centre for International Agricultural Research: Canberra, Australia, 2014; pp. 103-115.

48. Bussard, T. SDC Guideline for Sustainable Groundwater Resource Management; Swiss Agency for Development and Cooperation: Bern, Switzerland, 2016.

49. Viossanges, M.; Pavelic, P.; Rebelo, L.; Lacombe, G.; Sotoukee, T. Regional mapping of groundwater resources in data-scarce regions: The case of Laos. Hydrology 2017, 5, 2. [CrossRef]

50. Bai, B.; Cheng, Y.P.; Jiang, Z.C.; Zhang, C. Climate change and groundwater resources in Lao PDR. J. Groundw. Sci. Eng. 2017, 5, 53-58.

51. Khaing, K.K. Groundwater environment in Yangon, Myanmar. In Groundwater Environment in Asian Cities: Concepts, Methods and Case Studies; Shrestha, S., Pandey, V., Thatikonda, S., Shivakoti, B., Eds.; Butterworth-Heinemann: Oxford, UK, 2016; pp. 317-335. ISBN 9780128031667. [CrossRef]

52. Drury, L.W. Hydrogeology of the Dry Zone-Central Myanmar; Australian Water Partnership: Canberra, Australia, 2017; ISBN 9781921543333. 
53. Pavelic, P.; Sellamuttu, S.S.; Johnston, R.; McCartney, M.; Sotoukee, T.; Balasubramanya, S.; Suhardiman, D.; Lacombe, G.; Douangsavanh, S.; Joffre, O.; et al. Integrated Assessment of Groundwater Use for Improving Livelihoods in the Dry Zone of Myanmar; Research Report 164; International Water Management Institute (IWMI): Colombo, Sri Lanka, 2015.

54. Zaw, T.; Than, M.M. Climate change and groundwater resources in Myanmar. J. Groundw. Sci. Eng. 2017, 5, 31-43.

55. Pinto, D.; Shrestha, S. Groundwater Environment in Dili, Timor-Leste. Groundw. Environ. Asian Cities Concepts Methods Case Stud. 2016, 263-286. [CrossRef]

56. World Bank. Timor-Leste Water Sector Assessment and Roadmap about the Water Global Practice; World Bank: Washington, DC, USA, 2018.

57. Ximenes, M.; Duffy, B.; Faria, M.J.; Neely, K. Initial observations of water quality indicators in the unconfined shallow aquifer in Dili City, Timor-Leste: Suggestions for its management. Environ. Earth Sci. 2018, 77, 711. [CrossRef]

58. Wallace, L.; Sundaram, B.; Brodie, R.S.; Marshall, S.; Dawson, S.; Jaycock, J.; Stewart, G.; Furness, L. Vulnerability Assessment of Timor-Leste's Groundwater Resources to Climate Change; Geoscience Australia: Canberra, Australia, 2012; ISBN 978-1-922103-63-5.

59. Dục, L.V. Sanitation of Water Source and Treatment of Garbage and Wastes in Hanoi City. In Statement at East Asian and Middle-South American Conference on Environmental Industry; Ministry of Construction: Hanoi, Vietnam, 2012. Available online: https://www.mofa.go.jp/region/latin/fealac/pdfs/4-6_vietnam.pdf (accessed on 14 December 2018).

60. Leeuwen CJ, V.a.n.; Dan, N.P.; Dieperink, C. The Challenges of Water Governance in Ho Chi Minh City. Integr. Environ. Assess. Manag. 2015, 12, 345-352. [CrossRef] [PubMed]

61. Nguyen, Q.T. The main causes of land subsidence in Ho Chi Minh City. Procedia Eng. 2016, 142, 333-340. [CrossRef]

62. Wagner, F.; Tran, V.B.; Renaud, F.G. Groundwater Resources in the Mekong Delta: Availability, Utilization and Risks. In The Mekong Delta System: Interdisciplinary Analyses of a River Delta; Renaud, F.G., Kuenzer, C., Eds.; Springer: Dordrecht, The Netherlands, 2012; pp. 201-220. [CrossRef]

63. Chau, N.D.G.; Sebesvari, Z.; Amelung, W.; Renaud, F.G. Pesticide pollution of multiple drinking water sources in the Mekong Delta, Vietnam: Evidence from two provinces. Environ. Sci. Pollut. Res. Int. 2015, 9042-9058. [CrossRef] [PubMed]

64. Tam, V.T.; Batelaan, O.; Beyen, I. Impact assessment of climate change on a coastal groundwater system, Central Vietnam. Environ. Earth Sci. 2016, 75, 1-15. [CrossRef]

65. Shrestha, S.; Bach, T.V.; Pandey, V.P. Climate change impacts on groundwater resources in Mekong Delta under representative concentration pathways (RCPs) scenarios. Environ. Sci. Policy 2016, 61, 1-13. [CrossRef]

66. Post, V.E.A.; Bosserelle, A.L.; Galvis, S.C.; Sinclair, P.J.; Werner, A.D. On the resilience of small-island freshwater lenses: Evidence of the long-term impacts of groundwater abstraction on Bonriki Island, Kiribati. J. Hydrol. 2018, 564, 133-148. [CrossRef]

67. White, I.; Falkland, T. Management of freshwater lenses on small Pacific islands. Hydrogeol. J. 2010, $227-246$. [CrossRef]

68. Loco, A.; Singh, A.; Mataio, M.; Bwatio, E.; Sinclair, P. Kiriwatsan Water Resources Assessment Abaiang Island, Kiribati; UNICEF: Suva, Fiji, 2015.

69. Loco, A.; Sinclair, P.; Singh, A.; Mataio, M. Kiriwatsan Water Resources Assessment Maiana Island, Kiribati; UNICEF: Suva, Fiji, 2015.

70. ISF-UTS. Background Report on Kiribati Domestic Water Supplies and Climate Change; Institute for Sustainable Futures: Sydney, Australia, 2015.

71. Dixon-Jain, P.; Stewart, N.G.; Al, E. Pacific Island Groundwater and Future Climates; Geoscience Australia: Canberra, Australia, 2014; ISBN 9781925124323.

72. Government of Papua New Guinea. Papua New Guinea National Water, Sanitation and Hygiene Policy 2015; Department of National Planning and Monitoring: Port Moresby, Papua New Guinea, 2015.

73. SOPAC. Management in Pacific Island Countries National Integrated Water Resource Management; Diagnostic Report Papua New Guinea; Pacific Islands Applied GeoScience Commission (SOPAC): Suva, Fiji, 2007. 
74. IGRAC. Groundwater Monitoring in Small Island Developing States in the Pacific. In Proceedings of the Workshop Summary on Advancing Groundwater Monitoring in Pacific SIDS, Suva, Fiji, 29 August-2 September 2016; International Groundwater Resources Assessment Centre (IGRAC): Delft, The Netherlands, 2016.

75. Food and Agriculture Organization of the United Nations (FAO). AQUASTAT Survey 2011: Papua New Guinea; FAO: Rome, Italy, 2011.

76. Quigley, N.; Beavis, S.G.; White, I. Rainwater harvesting augmentation of domestic water supply in Honiara, Solomon Islands. Aust. J. Water Resour. 2016, 20, 65-77. [CrossRef]

77. World Bank. Urban Water Supply and Sanitation Sector Project (P165872) Project Information Document/Integrated Safeguards Data Sheet; Report No: PIDISDSC24841; World Bank: Washington, DC, USA, 2016.

78. Food and Agriculture Organization of the United Nations (FAO). AQUASTAT survey 2016 Solomon Islands; FAO: Rome, Italy, 2016.

79. SOPAC. National Integrated Water Resource Management Diagnostic Report-Solomon Islands; Pacific Islands Applied GeoScience Commission (SOPAC): Suva, Fiji, 2007.

80. Foster, T.; Willetts, J. Multiple water source use in rural Vanuatu: Are households choosing the safest option for drinking? Int. J. Environ. Health Res. 2018, 28, 579-589. [CrossRef] [PubMed]

81. Government of Vanuatu. Vanuatu National Water Strategy 2008-2018; Department of Geology Mines and Water Resources: Port Vila, Vanuatu, 2008.

82. Winkler, M.; Jackson, D.; Sutherland, D.; Payden; Lim, J.U.; Srikantaiah, V.; Fuhrimann, S.; Medlicott, K. Sanitation safety planning as a tool for achieving safely managed sanitation systems and safe use of wastewater. WHO South East Asia J. Public Heal. 2017, 6, 34. [CrossRef]

83. Berendes, D.M.; Sumner, T.A.; Brown, J.M. Safely managed sanitation for all means fecal sludge management for at least 1.8 billion people in low and middle income countries. Environ. Sci. Technol. 2017, 51, 3074-3083. [CrossRef] [PubMed]

84. Fienen, M.N.; Arshad, M. The International Scale of the Groundwater Issue. In Integrated Groundwater Management; Jakeman, A.J., Barreteau, O., Hunt, R.J., Rinaudo, J.-D., Ross, A., Eds.; Springer: Cham, Switzerland, 2016; pp. 21-48.

85. Morris, B.L.; Lawrence, A.R.L.; Chilton, P.J.C.; Adams, B.; Calow, R.C.; Klinck, B.A. Groundwater and Its Susceptibility to Degradation: A Global Assessment of the Problem and Options for Management; Early Warning and Assessment Report Series, RS. 03-3; United Nations Environment Programme: Nairobi, Kenya, 2003; Volume 53, ISBN 9788578110796.

86. Shrestha, S.; Pandey, V.P. Groundwater as an Environmental Issue in Asian Cities. In Groundwater Environment in Asian Cities: Case Studies, Concepts, and Methods; Shrestha, S., Pandey, V.P., Thatikonda, S., Shivakoti, B.R., Eds.; Elsevier Science \& Technology: Oxford, UK, 2016.

87. Foster, S. Urban Groundwater Dependency in Tropical Africa: A Scoping Study of Pro-Poor Implications; UPGro Working Paper; Skat Foundation: St.Gallen, Switzerland, 2017.

88. Calow, R.; MacDonald, A.; Denis Le Seve, M. The Environmental Dimensions of Universal Access to Safe Water. In Equality in Water and Sanitation Services; Cumming, O., Slaymaker, T., Eds.; Routledge: New York, NY, USA, 2018; pp. 95-117.

89. Grönwall, J. Self-supply and accountability: To govern or not to govern groundwater for the (peri-) urban poor in Accra, Ghana. Environ. Earth Sci. 2016, 75. [CrossRef]

90. Foster, S.; Bousquet, A.; Furey, S. Urban groundwater use in Tropical Africa-A key factor in enhancing water security? Water Policy 2018, 20, 982-994. [CrossRef]

91. Williams, A.R.; Bain, R.E.S.; Fisher, M.B.; Cronk, R.; Kelly, E.R.; Bartram, J. A systematic review and meta-analysis of fecal contamination and inadequate treatment of packaged water. PLoS ONE 2015, 10, e0140899. [CrossRef]

92. Kooy, M.; Walter, C.T. Towards a situated urban political ecology analysis of packaged drinking water supply. Water 2019, 11, 225. [CrossRef]

93. Stoler, J. Improved but unsustainable: Accounting for sachet water in post-2015 goals for global safe water. Trop. Med. Int. Heal. 2012, 17, 1506-1508. [CrossRef]

94. Wardrop, N.A.; Dzodzomenyo, M.; Aryeetey, G.; Hill, A.G.; Bain, R.E.S.; Wright, J. Estimation of packaged water consumption and associated plastic waste production from household budget surveys. Environ. Res. Lett. 2017, 12. [CrossRef] 
95. VNSO. 2016 Post-TC Mini-Census Report; Vanuatu National Statistics Office (VNSO): Port Vila, Vanuatu, 2017.

96. Vote, C.; Newby, J.; Phouyyavong, K.; Inthavong, T.; Eberbach, P. Trends and perceptions of rural household groundwater use and the implications for smallholder agriculture in rain-fed Southern Laos. Int. J. Water Resour. Dev. 2015, 31, 558-574. [CrossRef]

97. Warburton, E. Bottled Water-Big Business in Indonesia. Available online: https://blogs.ei.columbia.edu/ 2011/09/12/bottled-water-big-business-in-indonesia/ (accessed on 16 July 2018).

98. Elliott, M.; MacDonald, M.C.; Chan, T.; Kearton, A.; Shields, K.F.; Bartram, J.K.; Hadwen, W.L. Multiple Household water sources and their use in remote communities with evidence from Pacific Island countries. Water Resour. Res. 2017, 53, 9106-9117. [CrossRef]

99. Asian Development Bank. Asian Water Development Outlook 2016; Asian Development Bank: Manila, Philippines, 2016; Available online: https://www.adb.org/publications/asian-water-development-outlook2016 (accessed on 14 December 2018).

100. Smits, S.; Sutton, S. Self Supply: The Case for Leveraging Greater Household Investment in Water Supply; IRC: The Hague, The Netherlands, 2012.

101. Butterworth, J.; Sutton, S.; Mekonta, L. Self-supply as a complementary water services delivery model in Ethiopia. Water Altern. 2013, 6, 405-423.

102. Olschewsk, A. Supported Self-supply-Learning from 15 years of experiences. In Proceedings of the 7th RWSN Forum “Water for Everyone”, Abidjan, Côte d'Ivoire, 29 November-2 December 2016.

103. Willetts, J.; Murta, J.; Gero, A.; Carrard, N.; Harris, D. Political Economy Influences on Enterprise Engagement in Indonesia, Vietnam and Timor-Leste. In Water, Sanitation and Hygiene Services Beyond 2015-Improving Access and Sustainability, Proceedings of the 38th WEDC International Conference, Loughborough, UK, 27-31 July 2015; Shaw, R.J., Ed.; WEDC: Loughborough, UK, 2015.

104. Carrard, N.; Madden, B.; Chong, J.; Grant, M.; Nghiêm, T.P.; Bùi, L.H.; Hà, H.T.; Willetts, J. Are piped water services reaching poor households? Empirical evidence from rural Viet Nam. Water Res. 2019, 153, $239-250$. [CrossRef]

105. Asian Development Bank. Cambodia: Water Supply and Sanitation Sector Assessment, Strategy and Road Map; Asian Development Bank: Manila, Philppines, 2012; ISBN 9789290925682.

106. Hadipuro, W.; Indriyanti, N.Y. Typical urban water supply provision in developing countries: A case study of Semarang City, Indonesia. Water Policy 2009, 11, 55-66. [CrossRef]

107. Taylor, R.G.; Scanlon, B.; Döll, P.; Rodell, M.; Van Beek, R.; Wada, Y.; Longuevergne, L.; Leblanc, M.; Famiglietti, J.S.; Edmunds, M.; et al. Ground water and climate change. Nat. Clim. Chang. 2013, 3, 322-329. [CrossRef]

108. Luh, J.; Royster, S.; Sebastian, D.; Ojomo, E.; Bartram, J. Expert assessment of the resilience of drinking water and sanitation systems to climate-related hazards. Sci. Total Environ. 2017, 592, 334-344. [CrossRef]

109. Foster, S.; MacDonald, A. The 'water security' dialogue: Why it needs to be better informed about groundwater. Hydrogeol. J. 2014, 22, 1489-1492. [CrossRef]

110. Johannessen, Å.; Wamsler, C. What does resilience mean for urban water services? Ecol. Soc. $2017,22$. [CrossRef]

111. Kohlitz, J.; Chong, J.; Willetts, J. Analysing the capacity to respond to climate change: A framework for community-managed water services. Clim. Dev. 2019, 1-11. [CrossRef]

112. Sui, Q.; Cao, X.; Lu, S.; Zhao, W.; Qiu, Z.; Yu, G. Occurrence, sources and fate of pharmaceuticals and personal care products in the groundwater: A review. Emerg. Contam. 2015, 1, 14-24. [CrossRef]

113. Lapworth, D.J.; Baran, N.; Stuart, M.E.; Ward, R.S. Emerging organic contaminants in groundwater: A review of sources, fate and occurrence. Environ. Pollut. 2012, 163, 287-303. [CrossRef]

(C) 2019 by the authors. Licensee MDPI, Basel, Switzerland. This article is an open access article distributed under the terms and conditions of the Creative Commons Attribution (CC BY) license (http://creativecommons.org/licenses/by/4.0/). 